\title{
Ozone profile retrieval from limb scatter measurements in the HARTLEY bands: further retrieval details and profile comparisons
}

\author{
G. J. Rohen ${ }^{1}$, C. v. Savigny ${ }^{1}$, J. W. Kaiser ${ }^{2}$, E. J. Llewellyn ${ }^{3}$, L. Froidevaux ${ }^{4}$, M. López-Puertas ${ }^{5}$, T. Steck ${ }^{6}$, M. Palm ${ }^{1}$, \\ H. Winkler ${ }^{1}$, M. Sinnhuber ${ }^{1}$, H. Bovensmann ${ }^{1}$, and J. P. Burrows ${ }^{1}$ \\ ${ }^{1}$ Institute of Environmental Physics and Remote Sensing, Bremen, Germany \\ ${ }^{2}$ European Centre for Medium-Range Weather Forecasts, Reading, UK \\ ${ }^{3}$ Institute of Space and Atmospheric Studies, Saskatoon, Canada \\ ${ }^{4}$ Jet Propulsion Laboratory, Pasadena, USA \\ ${ }^{5}$ Instituto de Astrofísica de Andalucía, Granada, Spain \\ ${ }^{6}$ Institut für Meteorologie und Klimaforschung, Karlsruhe-Leopoldshausen, Germany
}

Received: 2 July 2007 - Published in Atmos. Chem. Phys. Discuss.: 16 August 2007

Revised: 22 April 2008 - Accepted: 23 April 2008 - Published: 9 May 2008

\section{COMMAND}

Abstract. SCIAMACHY limb scatter radiance measurements at selected wavelengths in the HARTLEY bands have been used to retrieve ozone profiles in the upper stratosphere and lower mesosphere. Comparisons with profiles measured by a ground based radiometer in Norway, MIPAS on board ENVISAT, HALOE on UARS and MLS on AURA indicate an agreement within $15 \%$ between 40 and $55 \mathrm{~km}$ and show that the retrieval provides reliable ozone profiles at these altitudes. Above $55 \mathrm{~km}$, an increasing overestimation is observed. Beside the profile comparisons, further retrieval features of the current retrieval (version 1.26) are described.

\section{Introduction}

Mesospheric ozone profiles are of interest, e.g. for investigations of Sun-Earth interactions like SPE s (Rohen et al., 2005) or of solar cycle effects. They are also required for modeling atmospheric dynamics, e.g. for climate forecasts.

First successful retrievals of mesospheric ozone profiles from limb-scattered solar radiation employed measurements from the UV-spectrometer on the Solar Mesosphere Explorer (SME) satellite (Thomas et al., 1980; Rusch et al., 1983). A routine retrieval of ozone in the HUGGINS bands from spectra measured by the Shuttle Ozone Limb Sounder Experi-

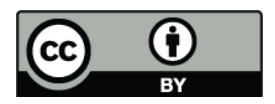

Correspondence to: G. J. Rohen (rohen@iup.physik.uni-bremen.de) ment (SOLSE) (McPeters et al., 2000) was difficult to establish due to a bad signal-to-noise ratio but introduced more sophisticated retrieval techniques which are now commonly used for retrievals from limb scatter measurements, e.g. doublet and triplet retrieval vector composition (Flittner et al., 2000). This paper provides further details on the retrieval algorithms and shows comparisons with profiles from a ground based radiometer, MIPAS on board ENVISAT, HALOE on UARS and MLS on AURA.

\section{SCIAMACHY limb measurements}

SCIAMACHY's (Bovensmann et al., 1999) local overflight times vary mostly around 10:00 a.m. during the day (see Fig. 1).

The spectrometer measures limb-scattered solar radiation from the Earth's surface up to $95 \mathrm{~km}$ tangent height in steps of about $3.3 \mathrm{~km}$ (Schwab et al., 1996), its instantaneous field of view in limb mode is $110 \times 2.6 \mathrm{~km}$ (horizontal $\times$ vertical) at the tangent point. The horizontal across track coverage is $960 \mathrm{~km}$ with a spatial resolution of $240 \mathrm{~km}$ at best, depending on the channel. For the spectral range used in this study only a single detector read-out is performed at each tangent height step leading to an across-track spatial resolution of $960 \mathrm{~km}$. One single vertical limb scan takes $60 \mathrm{~s}$. Within this period of time ENVISAT moves about $447 \mathrm{~km}$. Moreover, the tangent point moves towards the spacecraft during an upward scan. This effect corresponds to a horizontal distance

Published by Copernicus Publications on behalf of the European Geosciences Union. 


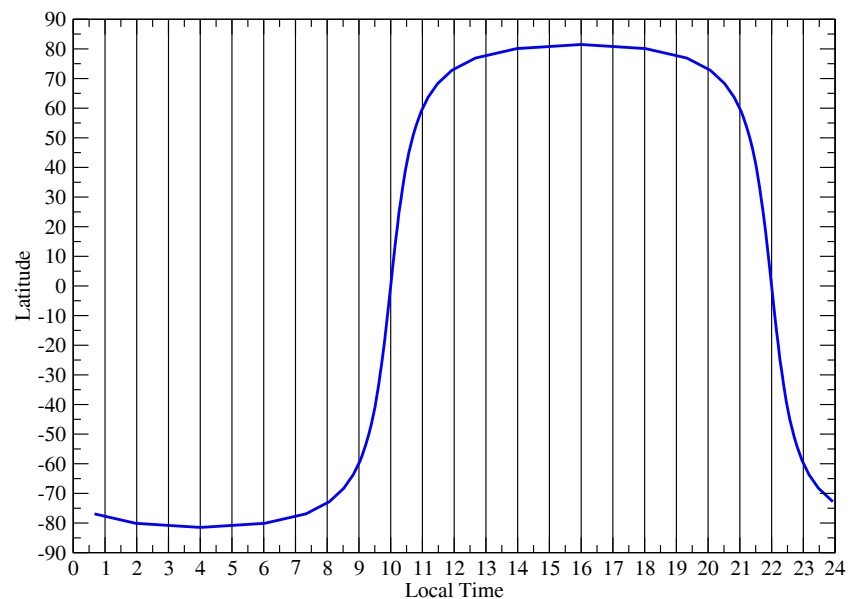

Fig. 1. ENVISAT local overflight times.

of about $145 \mathrm{~km}$. Both effects lead to an apparent movement of the tangent point of about $300 \mathrm{~km}$ in flight direction.

SCIAMACHY consists of eight channels covering the spectral range between 214 and $2384 \mathrm{~nm}$. The first channel covers the lowest spectral region up to $314 \mathrm{~nm}$ with a spectral resolution of $0.21 \mathrm{~nm}$ whose measurements are used for this presented retrieval.

\section{Retrieval methodology and algorithm}

The ozone profile retrieval methodology was originally proposed for air-borne limb measurements (e.g. Cunnold et al., 1973; Aruga and Heath, 1982). It is based on the fitting of measured and modeled limb radiance profiles at discrete wavelengths. The inversion technique applied to SME measurements, up to now the only successful ozone retrieval from satellite-borne limb limb scatter measurements in the UV-B, exploits radiances at 265 and $296.4 \mathrm{~nm}$ (Rusch et al., 1983); ozone profile retrievals at wavelengths in the HARTLEY bands from SOLSE observations (McPeters et al., 2000) have also been done using this method, but had difficulties due to a low signal-to-noise ratio. For their attempt of a routine profile retrieval, radiances at eleven discrete wavelengths between 300 and $355 \mathrm{~nm}$ have been used (McPeters et al., 2000). For this retrieval, the maximum of ozone absorption cross section in the HARTLEY bands (around $255 \mathrm{~nm}$ ) (Wayne, 1987; Burrows et al., 1999; Bogumil et al., 2003) is used for ozone profile retrievals at highest possible altitudes (see Rohen et al. (2005); Rohen (2006); Rohen et al. (2006) for a description of the algorithm).

Thirteen wavelengths were selected at 250, 252, 254, 264, $267.5,273,283,286,288,290.5,305,307$, and $310 \mathrm{~nm}$, avoiding emission lines while covering the full range in the HARTLEY bands (see Rohen (2006) for a detailed description of the potential contamination of limb scatter measure- ments by airglow emissions in the HARTLEY bands). Slight adjustments of the wavelengths have been done empirically.

The inversion of the measurement vector is performed by a nonlinear Optimal Estimation iteration scheme (Rodgers, 1976). For futher details of the retrieval methodology and algorithm we refer to previous publications (Rohen et al., 2005; Rohen, 2006; Rohen et al., 2006). However, the reached sensitivity of the retrieval to ozone is proposed to be between about 35 and $60 \mathrm{~km}$, sometimes $65 \mathrm{~km}$.

Weighting functions (Fig. 2) indicate that a continuous coverage of the sensitivity at these altitudes is given properly. Figure 3 shows fits and residuals for all thirteen wavelengths (sample fit). A bias can be seen at 250 and $254 \mathrm{~nm}$.

Averaged residuals between 35 and $65 \mathrm{~km}$ are below $3 \%$ (Rohen et al., 2005).

In terms of a priori, the retrieval is relatively insensitive with respect to the assumed a priori (see averaging kernels in Fig. 3 of Rohen et al., 2006). Retrieved profiles based on different a priori (50\% difference) differ by less than $4 \%$ for all relevant altitudes (Fig. 4). The multiple scattering contribution to the total limb radiance is relatively small, at least in the HARTLEY bands. The multiple scattering contribution for wavelengths below $300 \mathrm{~nm}$ is less than $1 \%$ (e.g., Oikarinen et al., 1999; Loughman et al., 2005). Figure 4 shows the relative double scattering contribution, derived with SCIARAYS.

At $60 \mathrm{~km}$ tangent height, this contribution corresponds to about $5 \%$ at $310 \mathrm{~nm}$ and decreases to $1 \%$ below $290 \mathrm{~nm}$. Sample inversions show that the induced differences in the retrieval due to the neglect of double scattering is below $2 \%$ at $40 \mathrm{~km}$ and decreases strongly with altitude. Therefore, only single scattering is considered in the retrieval.

One of the largest problems with SCIAMACHY limb data processing is still the tangent height misalignment (von Savigny et al., 2003). Many techniques have been suggested in order to improve the tangent height registration, e.g. using the shape of the radiance profiles (Janz et al., 1996; McPeters et al., 2000; Sioris et al., 2003; von Savigny et al., 2003). For this retrieval, tangent heights are corrected by tangent height offsets retrieved with the TRUE (Tangent height Retrieval by Ultraviolet-B Exploitation) version 1.4 technique (Kaiser et al., 2004; von Savigny et al., 2005). TRUE is based on an ozone-knee approach using the wavelength range between 295 and $305 \mathrm{~nm}$. The tangent height offsets - tropical mean values averaged over the $-20^{\circ}$ and $20^{\circ}$ latitude range - are applied to all limb measurements of a corresponding orbit. The tangent height accuracy is estimated to be about $500 \mathrm{~m}$ after TRUE. Figure 5 shows the effect of tangent height shifts of the limb radiances of $-2.5 \mathrm{~km}$ and $-0.5 \mathrm{~km}$ on a sample ozone profile retrieval. A tangent height error of $2.5 \mathrm{~km}$ leads to differences in the ozone concentrations of up to $90 \%$, and a $0.5 \mathrm{~km}$ tangent height inaccuracy results in errors of up to $17 \%$. The reason why this error increases with altitude is still unclear. At least, a connection to the decreasing ozone scale 

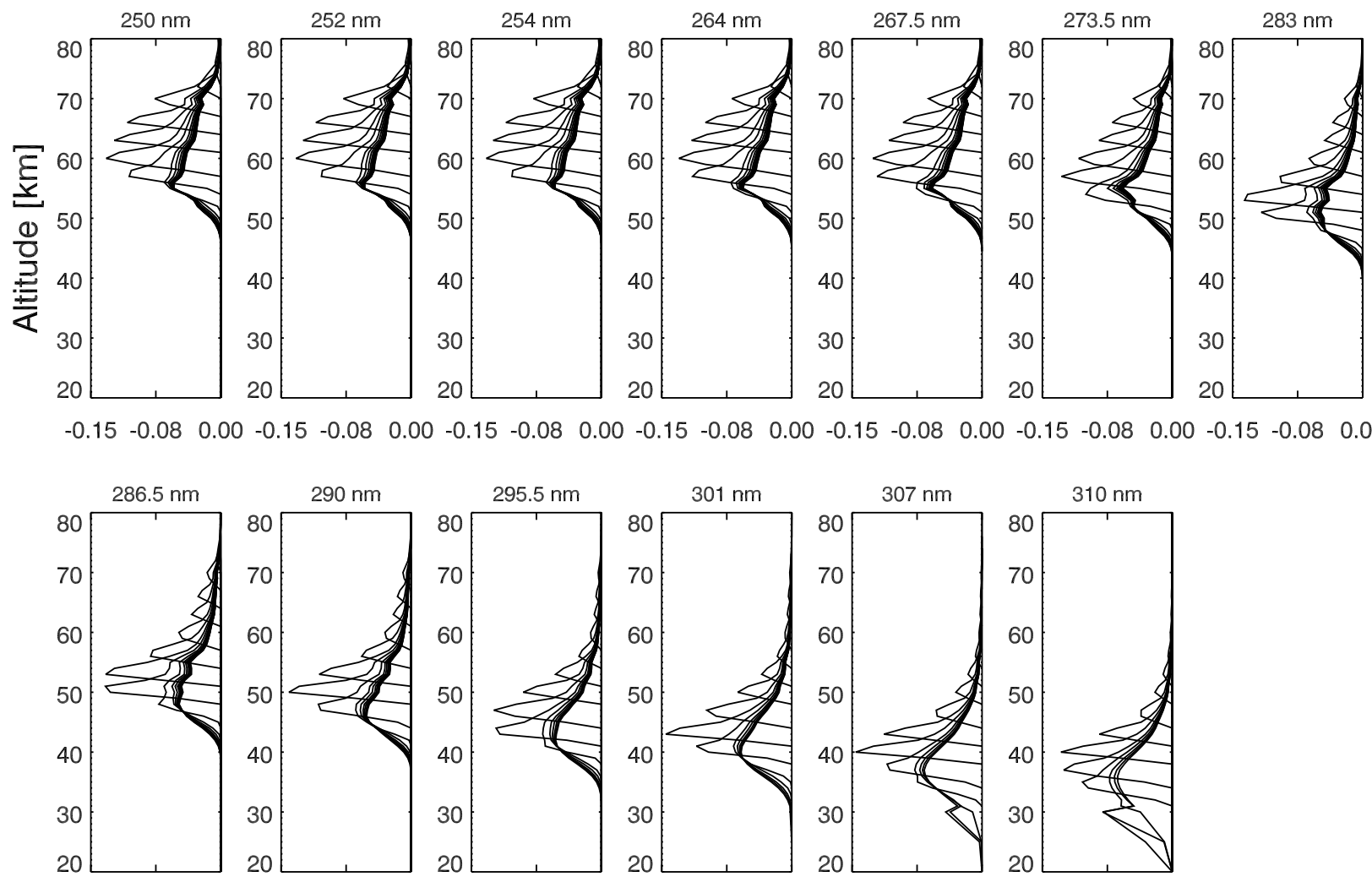

$\begin{array}{lllllllllllllllllll}-0.15 & -0.08 & 0.00 & -0.15 & -0.08 & 0.00 & -0.15 & -0.08 & 0.00 & -0.15 & -0.08 & 0.00 & -0.15 & -0.08 & 0.00 & -0.15 & -0.08 & 0.00\end{array}$

$\mathrm{d} \ln \left(\mathrm{l}_{\mathrm{I} k}{ }^{\text {norm }}\right) / \mathrm{d}\left(\ln \left[\mathrm{O}_{3}\right]\right)\left[\ln \left(\mathrm{cm}^{3} /\right.\right.$ molecule $\left.)\right]$

Fig. 2. Weighting functions for all thirteen wavelengths and all tangent heights from a sample profile retrieval. Solar zenith angle is $79^{\circ}$.

height is unlikely due to the relatively small change of the scale height.

External stray light is another potential error source which is referred to as the contamination from outside the field of view, e.g. from clouds and bright Earth. SCIAMACHY stray light was estimated at $310 \mathrm{~nm}$ by subtraction of the modeled from the measured radiances (Fig. 5); radiances smaller than $310 \mathrm{~nm}$ are less affected; van Soest, 2005). Stray light at $76 \mathrm{~km}$ reaches $120 \%$ of the in-field signal whereas the impact on the profile retrieval itself is negligible. Induced differences never exceed $1 \%$ between 35 and $65 \mathrm{~km}$; the normalization of the radiance profiles may help reducing the stray light effects. In summary, stray light has a large impact on the measurements only above around $70 \mathrm{~km}$, and hence has almost no effect on the retrieval in the region of interest between 40 and $60 \mathrm{~km}$.

\section{Profile comparisons}

Profile comparisons have been done with profiles measured by MIPAS on ENVISAT, the Radiometer for Atmospheric Measurements (RAM) at Spitsbergen, the HALogen Occul- tation Experiment (HALOE) on the Upper Atmosphere Research Satellite (UARS) and the Microwave Limb Sounder (MLS) on AURA. SCIAMACHY Level 1 version 5.04 and true version 1.4 have been used. Figure 6 shows the overall statistics for all instruments which are discussed in the next sections. The respective coincidence criteria are shown by the annotation in the respective figures. Measurements from the other instruments have been taken mostly in 2003 and 2004 covering the entire latitude bands.

The mean difference is below about $15 \%$, depending on the altitude, with mean $1 \sigma$ deviation of below $20 \%$. Comparisons with MLS and MIPAS profiles show an overestimation of the SCIAMACHY ozone concentrations at altitudes above 55 or $50 \mathrm{~km}$.

Figure 7 shows a statistics of 432 comparisons between retrieved ozone profiles and the used a priori profiles from a sample data set in 2003 and 2004. The mean agreement between the compared profiles is within $20 \%$. The standard deviations are obviously larger compared to those shown in Fig. 6 , e.g. $30 \%$ at $40 \mathrm{~km}$ or $60 \%$ at $50 \mathrm{~km}$. This shows the value added by the retrieval. 


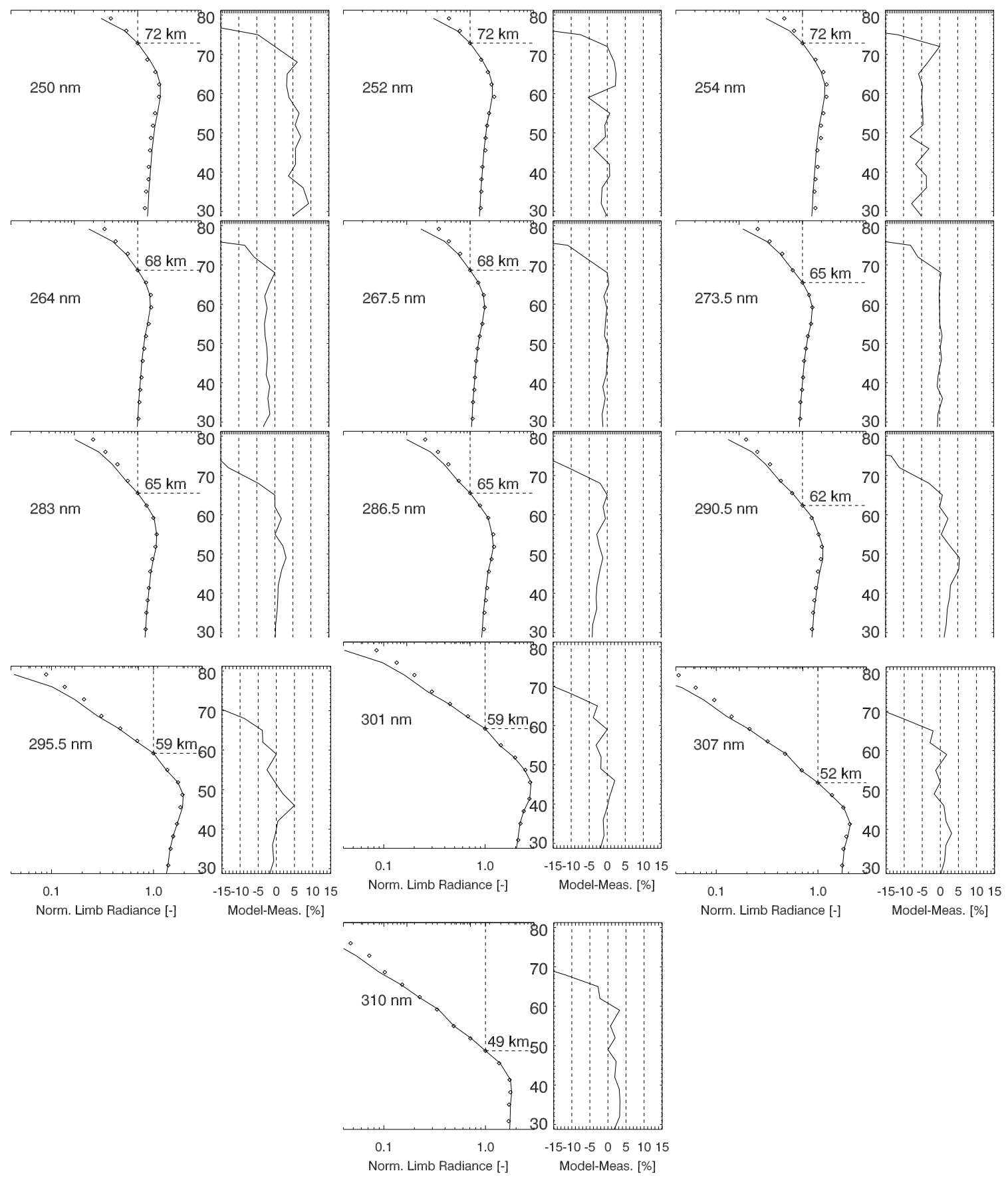

Fig. 3. Fits of limb radiance profiles for all thirteen wavelengths (sample profile retrieval, orbit 10945, number 1521, state 3). Dots in the respective left panels denote the measurement, the solid lines the model. Radiance profiles are normalized at a certain altitude, respectively, normalization points are denoted. Residuals are depicted in the right panel of the figures. The biases of the fits at 250 and $254 \mathrm{~nm}$ have not been found in every other sample retrieval. Above $70 \mathrm{~km}$, contamination of the measurements by stray light is the reason for the general underestimation of the model. 

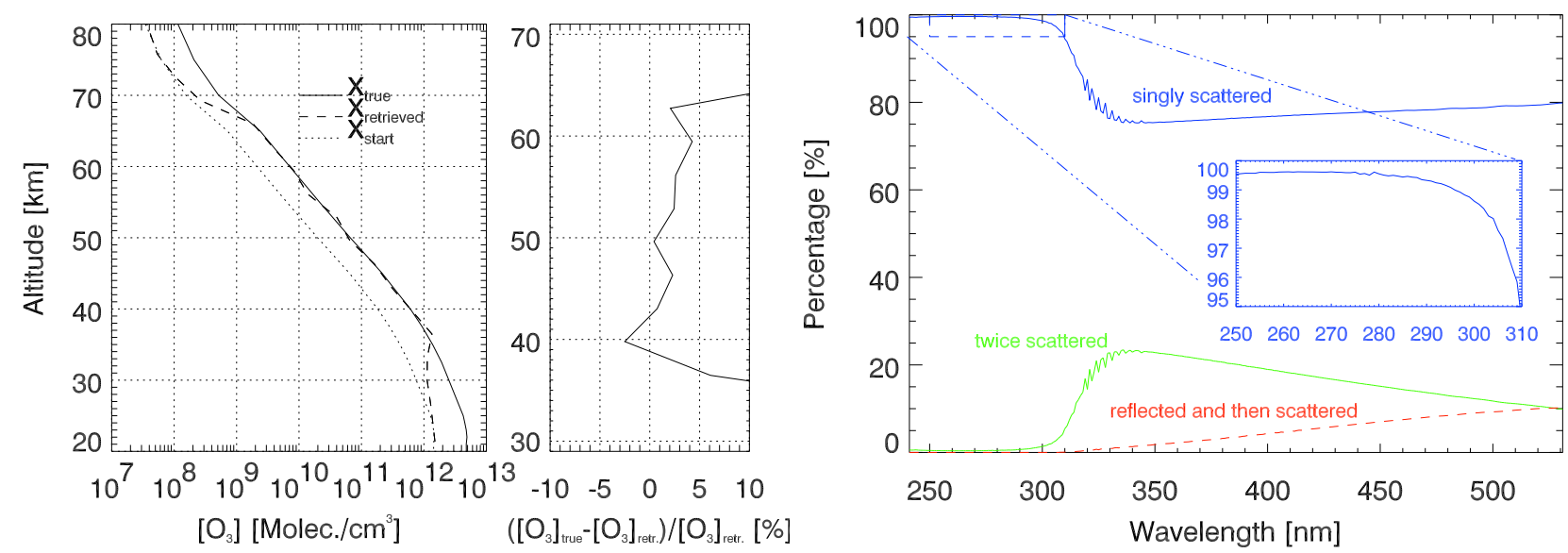

Fig. 4. Retrieval features: Differences caused by different a priori which distinguish by $50 \%$. $\mathrm{x}_{\text {start }}$ denotes the a priori. Right: Fraction of scattered and reflected photons at $60 \mathrm{~km}$ tangent height as modeled by SCIARAYS. Ozone absorption is considered, albedo=0.5. The fraction of double scattering at $30 \mathrm{~km}$ altitude is only slightly enlarged by a few percent relatively to that at $60 \mathrm{~km}$. The inner box shows an enlargement for wavelengths between 250 and $310 \mathrm{~nm}$.
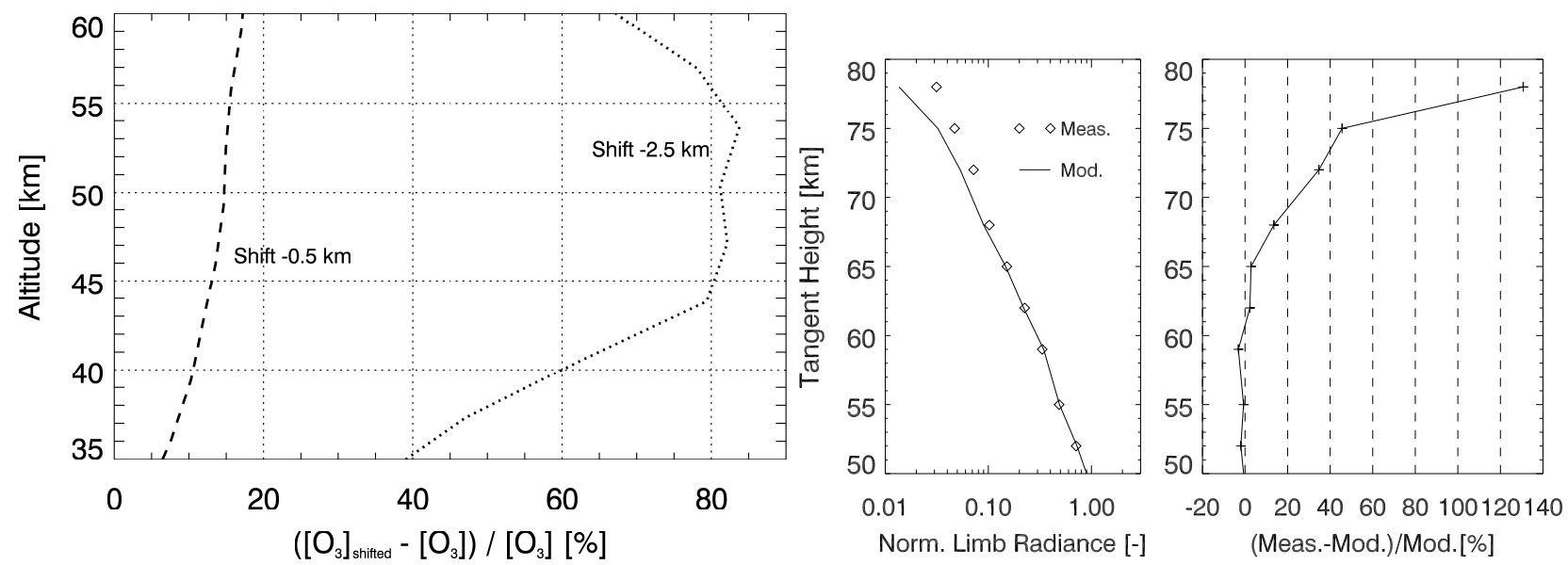

Fig. 5. Sensitivity studies: (a) differences in sample ozone profiles caused by $-0.5 \mathrm{~km}$ and $-2.5 \mathrm{~km}$ tangent height shifts. (b) Stray light contamination: simulated and measured limb radiances at $310 \mathrm{~nm}$ from a sample retrieval and their difference in percent.

Observations of ozone depletion during the Halloween solar storm in fall 2003 - using profiles from the presented profile retrieval - agree fairly well with observations of e.g. Global Ozone Monitoring by Occultation of Stars (GOMOS), or the Solar Backscatter Ultraviolet Instrument (SBUV II) (Rohen et al., 2005). Those comparisons also show the reliability of the profile retrieval in the altitudes between 40 and $60 \mathrm{~km}$, beside the fact that the retrieval even works under extreme conditions like during a solar storm.

The MIPAS ozone profiles used for this comparison were retrieved at the Institut für Meteorologie und Klimaforschung (IMK) (von Clarmann et al., 2001, 2003; Glatthor et al., 2005; Glatthor et al., 2006, and references therein) and provide a vertical coverage from $6 \mathrm{~km}$ to $68 \mathrm{~km}$. MIPAS's field of view is $30 \mathrm{~km}$ horizontally and $3 \mathrm{~km}$ vertically. The IMK
MIPAS ozone profiles were recently shown to agree with POAM III (Lumpe et al., 2003), LIDAR and ozone sonde measurements to within $10 \%$ for altitudes between $10 \mathrm{~km}$ and $60 \mathrm{~km}$ (Steck et al., 2007). MIPAS profiles have also been previously compared to SCIAMACHY stratospheric ozone observations and those of Global Ozone Monitoring by Occultation of Stars (GOMOS) (Bracher et al., 2005). In terms of GOMOS, the agreement of the compared profiles is also within $10 \%$ up to $60 \mathrm{~km}$ altitude. SCIAMACHY ozone profiles retrieved from an earlier processor version 2.16 have been compared already with MIPAS profiles in earlier studies (Rohen et al., 2006), but those have been retrieved with the operational ESA processor; they showed a slight underestimation. For the comparisons of our retrieved profiles with MIPAS profiles retrieved at the IMK, the following 

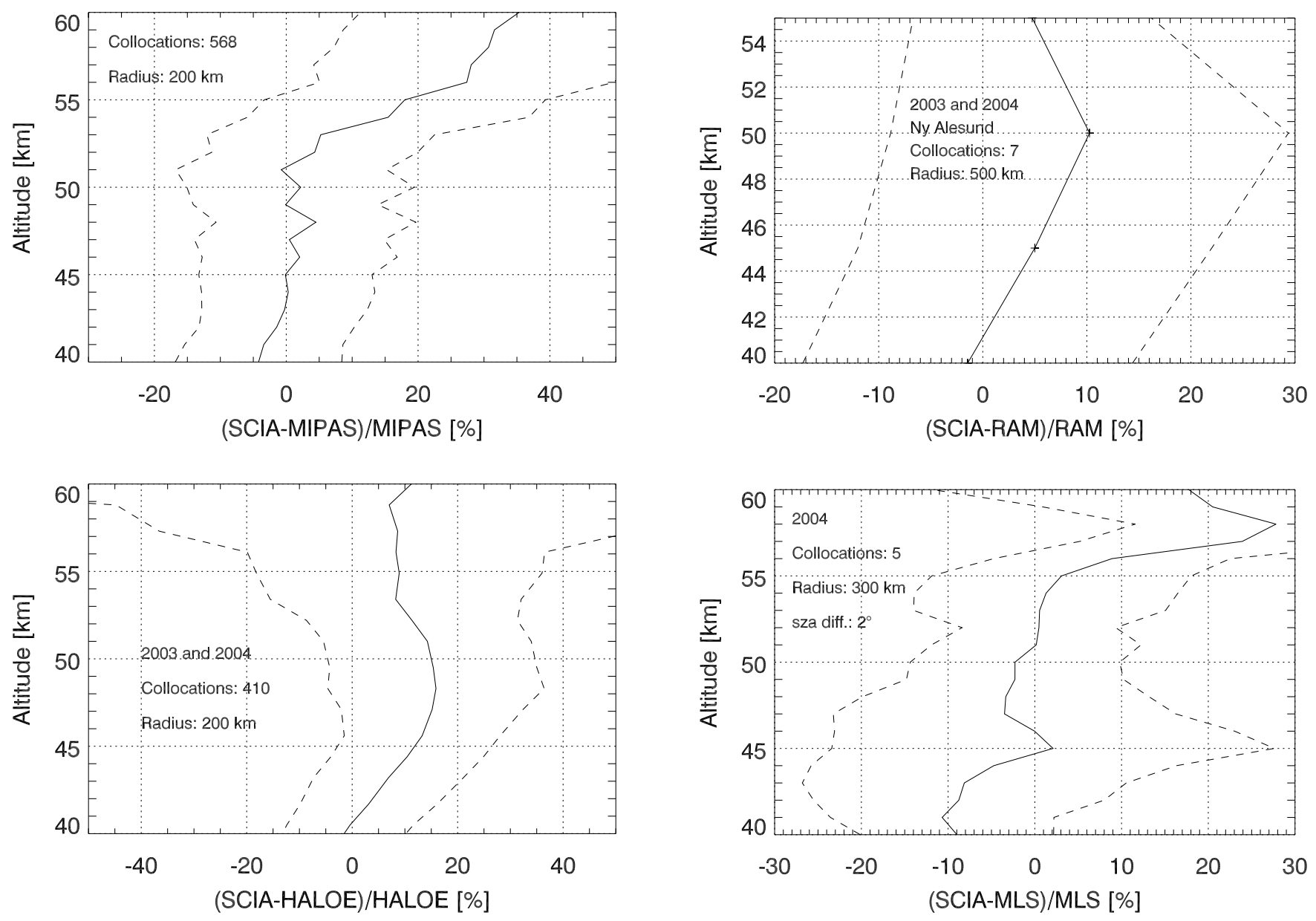

Fig. 6. Statistics from comparisons of SCIAMACHY (retrieval version 1.26) with profiles from MIPAS, RAM, HALOE, and MLS. Solid lines denote the mean deviation and dashed lines the $1 \sigma$ standard deviation. Only five collocations have been found in the case of MLS due to the strongly different local overflight times of the respective spacecrafts.

coincidence criteria were used: (a) the solar zenith angle of the measurements do not differ by more than $2^{\circ}$, (b) colocation radii of $100 \mathrm{~km}$ or $200 \mathrm{~km}$. We find good general agreement, but also increasing differences with altitude, particularly at altitudes above about $50 \mathrm{~km}$.

An inappropriate a priori ozone profile is not a likely candidate as a reason for the observed differences because the retrieved ozone concentrations are still fairly insensitive to the a priori at $55 \mathrm{~km}$ altitude. Furthermore, stray light was shown to have a small impact on the retrieval.

Comparisons of SCIAMACHY and MIPAS ozone profiles for different latitude bands and solar zenith angle show no significant changes in the comparisons.

The current HALOE (Russell et al., 1993) ozone retrieval version 1.9 provides profiles up to $70 \mathrm{~km}$. These were validated against numerous instruments, including ozone sondes, LIDAR s, balloons, rocketsondes, and satellites (Brühl et al., 1996; Rusch et al., 1997). HALOE ozone profiles are in good agreement with SAGE II measurements up to $50 \mathrm{~km}$ altitude.
Above $50 \mathrm{~km}$, HALOE observations were found to overestimate ozone by up to $20 \%$ due to incorrect photochemical corrections (Natarajan et al., 2005; Nazarayan et al., 2005). This finding requires confirmation by a more extensive statistical analysis since the Natarajan et al. (2005) and Nazarayan et al. (2005) analyses are only based on sample cases.

Solar occultation measurements like those of HALOE are performed at local times which are characterized by minimum ozone concentrations (see Fig. 8).

In order to compare HALOE observations with SCIAMACHY limb observations, a one dimensional version of the Single Layer Isentropic Model of Chemistry And Transport (SLIMCAT) model (Chipperfield, 1999) photochemical model has been used in order to derive HALOE ozone profiles to the SCIAMACHY solar zenith angle. Figure 8 shows exemplarily the ozone content at $90^{\circ}$ and $74^{\circ}$ solar zenith angle which differ by up to $20 \%$ below $60 \mathrm{~km}$ and up to several hundred percent above $60 \mathrm{~km}$ (see also Rohen (2006) for details). 


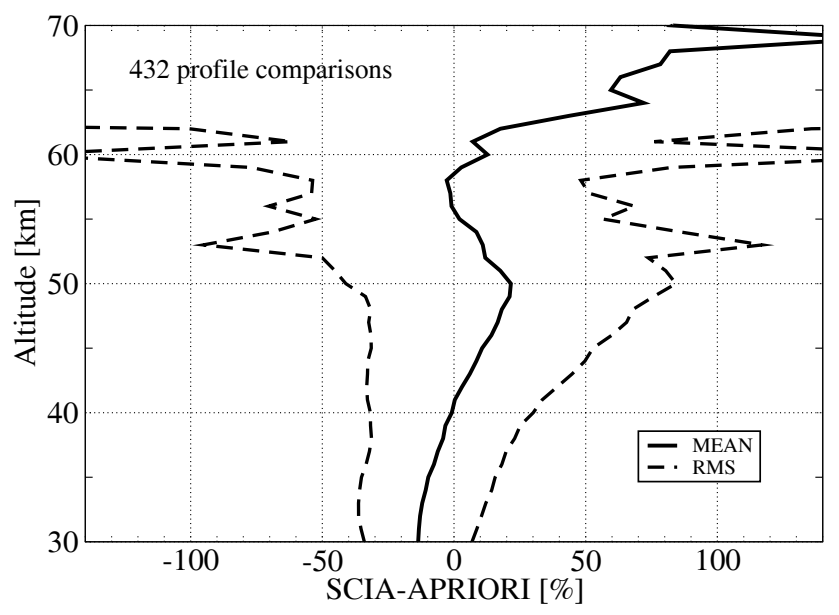

Fig. 7. Statistics from 432 comparisons between retrieved profiles and the corresponding used a priori profiles from a sample data set in 2003 and 2004.

The comparison between HALOE and SCIAMACHY profiles indicates a fairly good agreement in terms of the statistical mean (Fig. 6). But the modeled HALOE ozone profiles have large errors and make it therefore difficult to conclude on the quality of the SCIAMACHY profiles, at least above $50 \mathrm{~km}$. Below $50 \mathrm{~km}$, the agreement is fairly good, similar to the one observed with MIPAS.

Comparisons have also been done with ground based measurements from the Radiometer for Atmospheric Measurements (RAM) over $\mathrm{Ny}$ Ålesund $\left(78^{\circ} \mathrm{N}, 11^{\circ} \mathrm{E}\right)$, Norway (Langer, 1999). Retrieved ozone profiles cover 15 to $55 \mathrm{~km}$ and exhibit a vertical resolution between $8 \mathrm{~km}$ and $20 \mathrm{~km}$ (Palm et al., 2005). RAM profiles were validated by ozone sondes between $18 \mathrm{~km}$ and $24 \mathrm{~km}$ within $10 \%$, and with LIDAR instruments between $16 \mathrm{~km}$ and $34 \mathrm{~km}$ within $11 \%$ (Palm et al., 2005). MLS observations have been used for validation of RAM profiles between 20 and $55 \mathrm{~km}$ which also show an agreement within 10\% (Langer, 1999). In order to compare SCIAMACHY and RAM ozone, SCIAMACHY ozone profiles were convolved with averaging kernels of the RAM ozone inversion. In spite of the poor vertical resolution, collocated ozone profiles indicate an agreement within $10 \%$ (Fig. 6). Only a slight overestimation is observable above $50 \mathrm{~km}$, but this smaller differences above $50 \mathrm{~km}-$ as seen in the MIPAS comparisons - may be due to the poor vertical resolution of the RAM profiles. Again, a reliable statement of the quality of the retrieved profiles above $50 \mathrm{~km}$ through this comparison is difficult to give.

The last comparison has been done with profiles from the MLS instrument on AURA (version 1.5 (Froidevaux et al., 2006)). Validation has been done up to altitudes of $0.1 \mathrm{mbar}$ (about $48 \mathrm{~km}$ ) with ozone profiles measured by HALOE, Stratospheric Aerosol and Gas Experiment II (SAGE II), POAM III, and Atmospheric Chemistry Experiment (ACE).
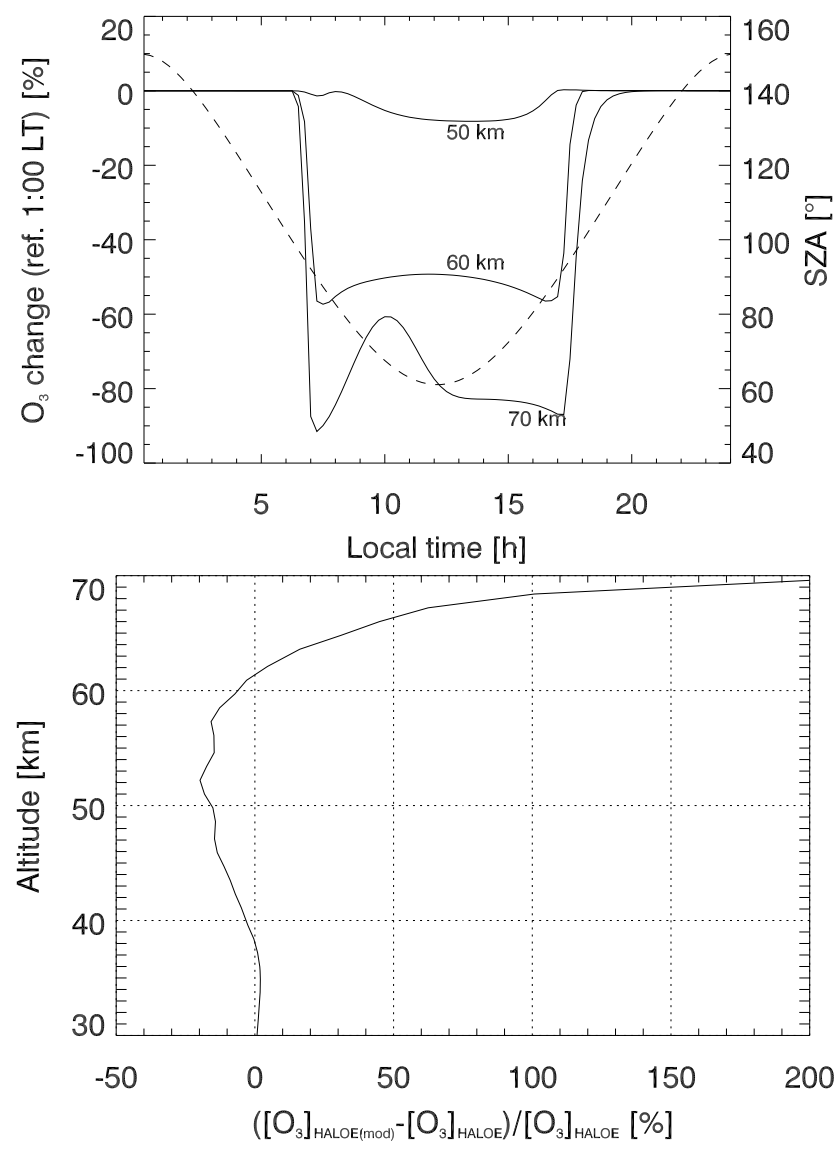

Fig. 8. SLIMCAT simulation of diurnal variability of ozone at 50, 60 and $70 \mathrm{~km}$ on 11 August 2002. The dashed line denotes the solar zenith angle and the solid lines denote the ozone changes at the respective altitudes. Right: Relative differences between a HALOE sample ozone profile - photochemically modeled to $74^{\circ}-$ and HALOE profile at $90^{\circ}$ solar zenith angle.

MLS ozone profiles agree well within 5\% with those profiles in the lower stratosphere but an underestimation in the upper stratosphere and an overestimation towards the mesosphere is has been observed. Although an upper limit of 0.46 mbar (about $54 \mathrm{~km}$ altitude) was recommended for the ozone product, good sensitivity in the upper mesosphere is also proposed (Livesey et al., 2005).

A statistics from collocated SCIAMACHY and MLS profiles within $300 \mathrm{~km}$ radius (Fig. 6, right, bottom) now shows a good agreement up to $55 \mathrm{~km}$, but an overestimation of the SCIAMACHY profiles above that height. In contrast to the MIPAS comparisons, large differences are found above approximately $56 \mathrm{~km}$, whereas such large differences are found already at $50 \mathrm{~km}$ in the case of MIPAS. Like in the comparisons with MIPAS profiles, increasing differences with altitude can be observed. 


\section{Conclusions}

SCIAMACHY/ENVISAT limb scatter measurements in the HARTLEY bands have been used to retrieve ozone profiles in the upper stratosphere and lower mesosphere (retrieval version 1.26) which show sensitivity between 35 and $65 \mathrm{~km}$ altitude, but in general, the retrieval provides reliable ozone profiles within about $15 \%$ accuracy between 40 and $55 \mathrm{~km}$. Above this altitude, retrieved profiles overestimate the true ozone content more and more with altitude.

Comparisons with ozone profiles from MIPAS on ENVISAT, HALOE on UARS, a ground based radiometer in Norway, and MLS on board AURA confirm this, differences are of about $15 \%$ up to $55 \mathrm{~km}$ and an increasing overestimation above $55 \mathrm{~km}$ can be seen. In the future, the findings from this profile retrieval together with those from the ozone retrievals in the HUGGINS and CHAPPUIS bands will help to provide ozone profiles between 10 and $55 \mathrm{~km}$ from SCIAMACHY limb measurements.

Acknowledgements. This work was in part supported by the German Ministry of Education and Research BMBF (grant 07UFE12/8), the German Aerospace Center DLR (grant 50EE0027), the University of Bremen, and through grantsin-aid from the Natural Sciences and Engineering Research Council (NSERC) of Canada. We thank the European Space Agency (ESA) for providing the SCIAMACHY data used in this study. Furthermore, we are indebted to all members of the SCIAMACHY team whose efforts make all data analysis possible.

Edited by: V. Fomichev

\section{References}

Aruga, T. and Heath, D. F.: Determination of vertical ozone distributions by spacecraft measurements using limb-scan technique, Appl. Opt., 21, 3047-3054, 1982.

Bogumil, K., Orphal, J., Homann, T., Voigt, S., Spietz, P., Fleischmann, O. C., Vogel, A., Hartmann, M., Bovensmann, H., Frerick, J., and Burrows, J. P.: Measurements of molecular absorption spectra with the SCIAMACHY pre-flight model: Instrument characterization and reference data for atmospheric remote sensing in the 230-2390 nm region, J. Photochem. Photobiol. A, 157, 167-184, 2003.

Bovensmann, H., Burrows, J. P., Frerick, J., Noël, S., Rozanov, V. V., Chance, K. V., and Goede, A. P. H.: SCIAMACHY: Mission objectives and measurements modes, J. Atmos. Sci., 56, 127-148, 1999.

Bracher, A., Bovensmann, H., Bramstedt, K., Burrows, J. P., von Clarmann, T., Eichmann, K.-U., Fischer, H., Funke, B., GilLópez, S., Glatthor, N., Grabowski, U., Höpfner, M., Kaufmann, M., Kellmann, S., Kiefer, M., Koukouli, M. E., Linden, A., López-Puertas, M., Tsidu, G. M., Milz, M., Noël, S., Rohen, G., Rozanov, A., Rozanov, V. V., v. Savigny, C., Sinnhuber, M., Skupin, J., Steck, T., Stiller, G. P., Wang, D.-Y., Weber, M., and Wuttke, M. W.: Cross comparisons of $\mathrm{O}_{3}$ and
$\mathrm{NO}_{2}$ measured by the atmospheric ENVISAT instruments GOMOS, MIPAS, and SCIAMACHY, Adv. Space Res., 36, 855867, doi:10.1016/j.asr.2005.04.005, 2005.

Brühl, C., Drayson, S. R., Russell, J. M., Crutzen, P. J., McInerney, J. M., Purcell, P. N., Claude, H., Gernandt, H., McGee, T. J., McDermid, I. S., and Gunson, M. R.: Halogen occultation experiment ozone channel validation, J. Geophys. Res., 101, $10217-$ 10 240, doi:10.1029/95JD02031, 1996.

Burrows, J. P., Richter, A., Dehn, A., Deters, B., Himmelmann, S., Voigt, S., and Orphal, J.: Atmospheric remote-sensing reference data from GOME: 2. Temperature-dependent absorption cross sections of $\mathrm{O}_{3}$ in the 231-794 nm range, J. Quant. Spectrosc. Radiat. Transfer, 61, 509-517, 1999.

Chipperfield, M. P.: Multiannual simulations with a three dimensional chemical transport model, J. Geophys. Res., 104, 1781$1805,1999$.

Cunnold, D. M., Gray, C. R., and Merrit, D. C.: Stratospheric aerosol layer detection, J. Geophys. Res., 78, 920-931, 1973.

Flittner, D. E., Bhartia, P. K., and Herman, B. M.: $\mathrm{O}_{3}$ profiles retrieved from limb scatter measurements: Theory, Geophys. Res. Lett., 27, 2601-2604, 2000.

Froidevaux, L., Livesey, N. J., Reid, W. G., Jiang, Y. B., Jimenez, C., Filipiak, M. J., Schwartz, M. J., Santee, M. L., Purnphrey, H. C., Jiang, J. H., Wu, D. L., Manney, G. L., Drouin, B. J., Waters, J. W., Fetzer, E. J., Bernath, P. F., Boone, C. D., Walker, K. A., Jucks, K. W., Toon, G. C., Margitan, J. J., Sen, B., Webster, C. R., Christensen, L. E., Elkins, J. W., Atlas, E., Lueb, R. A., and Hendershot, R.: Early Validation Analysis of Atmospheric Profiles from EOS MLS on the Aura Satellite, IEEE Trans. Geosc. Rem. Sens., 44, 1106-1121, 2006.

Glatthor, N., von Clarmann, T., Fischer, H., Funke, B., Grabowski, U., Höpfner, M., Kellmann, S., Kiefer, M., Linden, A., Milz, M., Steck, T., Stiller, G. P., Mengistu Tsidu, G., and Wang, D. Y.: Mixing processes during the Antarctic vortex split in September/October 2002 as inferred from source gas and ozone distributions from ENVISAT-MIPAS, J. Atmos. Sci., 62, 787-800, 2005.

Glatthor, N., von Clarmann, T., Fischer, H., Funke, B., Gil-López, S., Grabowski, U., Höpfner, M., Kellmann, S., Linden, A., López-Puertas, M., Mengistu Tsidu, G., Milz, M., Steck, T., Stiller, G. P., and Wang, D.-Y.: Retrieval of stratospheric ozone profiles from MIPAS/ENVISAT limb emission spectra: a sensitivity study, Atmos. Chem. Phys., 6, 2767-2781, 2006, http://www.atmos-chem-phys.net/6/2767/2006/.

Janz, S. J., Hilsenrath, E., Flittner, D., and Heath, D.: Rayleigh scattering attitude sensor, Proc. of SPIE, 2831, 146-153, 1996.

Kaiser, J. W., von Savigny, C., Eichmann, K.-U., Noël, S., Bovensmann, H., and Burrows, J. P.: Satellite-pointing retrieval from atmospheric limb-scattering of solar UV-B radiation, Can. J. Phys., 82, 1041-1052, 2004.

Langer, J.: Comparison of ozone-measurements at Ny Ålesund, Spitsbergen, in 1997 and 1998, Ph.D. thesis, University of Bremen, in German, 1999.

Livesey, N. J., Read, W. G., Filipiak, M. J., Froidevaux, L., Harwood, R. S., Jiang, J. H., Jimenez, C., Pickett, H. M., Pumphrey, H. C., Santee, M. L., Schwartz, M. J., Waters, J. W., and Wu, D. L.: Earth Observing System (EOS) Microwave Limb Sounder (MLS) Version 1.5 Level 2 data quality and description document, Tech. Rep. JPL D-32381, Jet Propulsion Laboratory, Cali- 
fornia Institute of Technology, Pasadena, California, 2005.

Loughman, R. P., Flittner, D. E., Herman, B. M., Bhartia, P. K., Hilsenrath, E., and McPeters, R. D.: Description and sensitivity analysis of a limb scattering ozone retrieval algorithm, J. Geophys. Res., 110, D19 301, doi:10.129/2004JD005429, 2005.

Lumpe, J. D., Randall, C. E., Bevilacqua, R. M., Hoppel, K. W., Nedoluha, G. E., and Prados, A. I.: POAM III Validation Summary, AGU Fall Meeting Abstracts, p. D711, 2003.

McPeters, R. D., Janz, S. J., Hilsenrath, E., Brown, T. L., Flittner, D. E., and Heath, D. F.: The retrieval of ozone profiles from limb scatter measurements: Results from the Shuttle Ozone Limb Sounding Experiment, Geophys. Res. Lett., 27, 25972600, 2000.

Natarajan, M. L., Deaver, L. E., Thompson, E., and Magill, B.: Impact of twilight gradients on the retrieval of mesospheric ozone from HALOE, J. Geophys. Res., 110, 2005.

Nazarayan, H., McCormick, M. P., and Russell, J. M.: New studies of SAGE II and HALOE ozone profile and long-term change comparisons, J. Geophys. Res. (Atmos.), 110, 9305, 2005.

Oikarinen, L., Sivhola, E., and Kyrölä, E.: Multiple-scattering radiance in limb-viewing geometry, J. Geophys. Res., 104, 31 261$31274,1999$.

Palm, M., von Savigny, C., Warneke, T., Velazco, V., Notholt, J., Künzi, K., Burrows, J., and Schrems, O.: Intercomparison of $\mathrm{O}_{3}$ profiles observed by SCIAMACHY and ground based microwave instruments, Atmos. Chem. Phys., 5, 2091-2098, 2005, http://www.atmos-chem-phys.net/5/2091/2005/.

Rodgers, C. D.: Retrieval of atmospheric temperature and composition from remote measurements of thermal radiation, Rev. Geophys. Space Phys., 14, 609-624, 1976.

Rohen, G., von Savigny, C., Sinnhuber, M., Llewellyn, E. J., Kaiser, J. W., Jackman, C. H., Kallenrode, M.-B., Schröter, J., Eichmann, K.-U., Bovensmann, H., and Burrows, J. P.: Ozone depletion during the solar proton events of October/November 2003 as seen by SCIAMACHY, J. Geophys. Res., 110, A09S39, doi:10.1029/2004JA010984, 2005.

Rohen, G. J.: Retrieval of Upper Stratospheric and Lower Mesospheric Ozone Profiles from SCIAMACHY Limb Scatter Measurements and Observations of the Ozone Depletion During the Solar Proton Event in October and November 2003, Logos Publication, Berlin, Ph.-D. thesis, ISBN 978-3-3825-1363-4, ISSN 1615-6862, 2006.

Rohen, G. J., von Savigny, C., Llewellyn, E. J., Kaiser, J. W., Eichmann, K.-U., Bracher, A., Bovensmann, H., and Burrows, J. P.: First results of ozone profiles between 35 and $65 \mathrm{~km}$ retrieved from SCIAMACHY limb spectra and observations of ozone depletion during the solar proton events in Oct./Nov. 2003, Adv. Space Res., 37, 2263-2268, doi:10.1016/j.asr.200503.160, 2006.

Rusch, D. W., Mount, G. H., Barth, C. A., Rottmann, G. J., Thomas, R. J., Thomas, G. E., Sanders, R. W., Lawrence, G. M., and Eckman, R. S.: Ozone densities in the lower mesosphere measured by a limb scanning UltraViolet Spectrometer, Geophys. Res. Lett., 10, 241-244, 1983.

Rusch, D. W., Bevilacqua, R. M., Randall, C. E., Lumpe, J. D., Hoppel, K. W., Fromm, M. D., Debrestian, D. J., Olivero, J. J., Hornstein, J. H., Guo, F., and Shettle, E. P.: Validation of POAM ozone measurements with coincident MLS, HALOE, and SAGE II observations, J. Geophys. Res., 102, 23 615-23 628, 1997.
Russell, J. M., Gordley, L. L., Park, J. H., Drayson, S. R., Hesketh, W. D., Cicerone, R. J., Tuck, A. F., Frederick, J. E., Harries, J. E., and Crutzen, P. J.: The Halogen Occultation Experiment, J. Geophys. Res., 98, 10777-10797, 1993.

Schwab, A., Mager, R., and Fricke, W.: SCIAMACHY pointing error budget, Tech. Rep. Tn-Scia-0000Do/06, A, Dornier, 1996.

Sioris, C. E., Haley, C. S., McLinden, C. A., von Savigny, C., McDade, I. C., McConnell, J. C., Evans, W. F. J., Lloyd, N. D., Llewellyn, E. J., Chance, K. V., Kurosu, T. P., Murtagh, D., Frisk, U., Pfeilsticker, K., Bösch, H., Weidner, F., Strong, K., Stegman, J., and Mégie, G.: Stratospheric profiles of nitrogen dioxide observed by OSIRIS on the ODIN satellite, J. Geophys. Res., 108, 4215-4234, doi:101029/2002JD002672, 2003.

Steck, T., von Clarmann, T., Fischer, H., Funke, B., Glatthor, N., Grabowski, U., Höpfner, M., Kellmann, S., Kiefer, M., Linden, A., Milz, M., Stiller, G. P., Wang, D. Y., Allaart, M., Blumenstock, T., von der Gathen, P., Hansen, G., Hase, F., Hochschild, G., Kopp, G., Kyrölä, E., Oelhaf, H., Raffalski, U., Marrero, A. R., Remsberg, E., III, J. R., Stebel, K., Steinbrecht, W., Wetzel, G., Yela, M., and Zhang, G.: Bias determination and precision validation of ozone profiles from MIPAS-ENVISAT retrieved with the IMK-IAA processor, Atmos. Chem. Phys., 7, 4427-4480, 2007, http://www.atmos-chem-phys.net/7/4427/2007/.

Thomas, G. E., Barth, C. A., Hansen, E. R., Hord, C. W., Mount, G. M., Rottman, G. H., Rusch, D. W., Stewart, A. I., Thomas, R. J., London, J., Bailey, P. L., Crutzen, P. J., Dickenson, R. E., Gille, J. C., Liu, S. C., Noxon, J. J., and Farmer, C. B.: Scientific objectives of the Solar Mesosphere Explorer mission, Pure Appl. Geophys., 118, 591-615, 1980.

van Soest, G.: Investigation of SCIAMACHY limb spatial straylight, Tech. Rep. SRON-Eos-rp-05-006, SRON, 2005.

von Clarmann, T., Fischer, H., Funke, B., Glatthor, N., Grabowski, U., Höpfner, M., Kiefer, M., Martin-Torres, F. J., Milz, M., and Stiller, G. P.: MIPAS interactive semi-operational level-2 data processing, in: Current Problems in Atmospheric Radiation, edited by Smith, W. L. and Timofeyev, Y. M., pp. 785-788, A. Deepak Publ., Hampton, Va., 2001.

von Clarmann, T., Glatthor, N., Grabowski, U., Höpfner, M., Kellmann, S., Kiefer, M., Linden, A., Mengistu Tsidu, G., Milz, M., Steck, T., Stiller, G. P., Wang, D. Y., Fischer, H., Funke, B., GilLópez, S., and López-Puertas, M.: Retrieval of temperature and tangent altitude pointing from limb emission spectra recorded from space by the Michelson Interferometer for Passive Atmospheric Sounding (MIPAS), J. Geophys. Res., 108, 2003.

von Savigny, C., Rozanov, A., Bovensmann, H., and Kaiser, J. W.: SCIAMACHY limb pointing analysis report, Tech. rep., University of Bremen, 2003.

von Savigny, C., Kaiser, J. W., Bovensmann, H., Burrows, J. P., McDermid, I. S., and Leblanc, T.: Spatial and temporal characterization of SCIAMACHY limb pointing errors during the first three years of the mission, Atmos. Chem. Phys., 5, 2593-2602, 2005, http://www.atmos-chem-phys.net/5/2593/2005/.

Wayne, R. P.: The photochemistry of ozone, Atmos. Env., 21, 1683$1694,1987$. 